\title{
Successful Earners and Failing Others. Transnational Orientation as Biographical Resource in the Context of Labor Migration \\ Magdalena Nowicka
}

Fachgebiet: Migration

Schlagwörter: Misserfolg; Erfolg; biographische Narrationen; Handlungstheorie; polnische Migration

Keywords: failure, success, biographical narrations, action theory, Polish migration

\section{Erstveröffentlicht in:}

Nowicka, Magdalena (2014): Successful Earners and Failing Others. Transnational Orientation as Biographical Resource in the Context of Labor Migration. In: International Migration, 52 (1): 74-86.

DOI: $10.1111 /$ imig. 12144

The final article is available at Wiley Online Library via:

http://onlinelibrary.wiley.com/doi/10.1111/imig.12144/abstract

\section{(C) 2014 John Wiley \& Sons Ltd.}

This is the final draft post-refereeing version of the following article: Nowicka, Magdalena (2014): Successful Earners and Failing Others. Transnational Orientation as Biographical Resource in the Context of Labor Migration. In: International Migration, 52 (1): 74-86, which has been published in final form at:

http://onlinelibrary.wiley.com/doi/10.1111/imig.12144/abstract. This article may be used for non-commercial purposes in accordance with Wiley Terms and Conditions for Self-Archiving. There may be differences between this version and the published version. You are advised to consult the publisher's version if you wish to cite from it.

\section{Prof. Dr. Magdalena Nowicka}

Professur für Migration und Transnationalismus

Humboldt-Universität zu Berlin

Institut für Sozialwissenschaften

Tel: 0049 (30) 20934239

Fax: 0049 (30) 20934519

magdalena.nowicka@hu-berlin.de

\section{Arbeits- und Forschungsschwerpunkte}

Soziologische Migrationsforschung, soziale Ungleichheit in transnationaler Perspektive,

Mobilitätsparadigma, Kosmopolitismus, Theorien der Modernisierung und Globalisierung,

Transnationalismus, qualitative Methoden, empirische Forschung 


\title{
Successful Earners and Failing Others. Transnational Orientation as Biographical Resource in the Context of Labor Migration
}

\begin{abstract}
The article discusses how post-2004 Polish immigrants in Great Britain narrate success and failure in their lives. It identifies and analyzes inter-related narrations specific to the transnational form of migration. It considers migrants' transnational orientation as a resource for narratively producing a successful biography. The article makes use of a biographical perspective and embeds the analysis in theories of biographical action, while adding new knowledge to the scholarship of migration. It argues that failure is relative to a normatively, locally fixed expectation of success.
\end{abstract}

Keywords: failure, success, biographical narrations, action theory, Polish migration

\section{Introduction}

If sociology directs its attention to processes that operate successfully (Malpas and Wickham, 1995: 38), conventional studies of migration are interested in what does not work: labor markets' incapability to accommodate immigrant workers; the emergence of new structures of inequality; spatial and social segregation; racism. In this vain research on return migration considers failure as motivation to (postponed) return migration. These studies share a tendency to consider failure from the perspective of a normative desired ideal of successful societal integration that results from a "nation-state lens" (Wimmer and Glick Schiller, 2002). Nation-states structure thereby what sociologists call a "normal" biography: the relatively predictable and linear life course marked by engagement in education, paid work, household formation and retirement, seen to have characterized most of those born in the Western world post-World War II (Kohli, 2007).

Scholarship on migration devoted to a transnational perspective provides several arguments for a new view on success and failure. First, by seeing social incorporation in multiple rather than single social spaces, it points to the local definitions of success and failure (Kelly and Lusis, 2006). Second, it shows that migrants, by switching between two or more contexts, may use their transnational orientation (Nowicka 2012) as a biographical resource (Apitzsch and Kontos, 2008). Third, transnational studies prove how multiple organized memberships provide migrants with the capacity to command scarce resources such as money, prestige, social recognition, or employment (Caglar and Glick Schiller, 2008; Nowicka, 2013) in ways unavailable to non-migrants. Thus, living within a transnational social space can - and this is what I investigate in this contribution - influence how migrants perceive success and failure as part of their biography.

Investigating narratives from in-depth interviews with 44 Polish post-2004 immigrants to the UK, I depict their understandings of success and gradually approach the notion of failure. The aim of 
the paper is to contribute to the sociological discussion on failure by discussing the narratives on success and failure that are specific to a transnational form of migration. At the same time, the article adds to the scholarship on migration. Conventional migration studies consider failure - a condition of not having achieved personal goals - a drive to return migration (for discussion see Wang and Fan 2006). This is not true for Polish migrants in the UK who stay despite unsuccessful labor market integration (White 2013). Yet unlike the new economics of labor migration which argue that return is postponed by failure (de Haas and Fokkema 2011) I first detach the question of failure and success from the motivation to return. Grounding my thesis in empirical material, I argue that failure is relative to a normatively fixed, locally and historically produced, expectation of success. By constructing successful biographies across nation-state borders, migrants gain new options for biographical action. Considering this in the light of migrants' motivation to return, we gain a better understanding of why migrants settle or return.

I proceed with the discussion of how failure and success are conceptualized in sociology. I move on to present the analytical framework which derives from biographical research on risk and uncertainty but is largely a result of the analysis of my own empirical data. I then present my sample and methods of investigation. The main part of the article is dedicated to discussion of selected empirical findings which I organized focusing on different narratives on success and on failure. I conclude by stressing how transnational orientations of migrants become a resource to discursively produce a successful biography, and what lessons can be drawn from this result for the sociology of migration.

\section{Sociological perspectives on failure and success}

Failure and success has mostly been a subject of investigation within the sociology of markets and organizations where it is an artifact of the application of performance criteria (Ackroyd, 2007). Malpas and Wickham (1995: 37) argue that general sociology favors success because it is attentive to what social actors do - and they tend to present themselves as successful actors. Junge (2010:34) draws the attention to another shortage that is rooted in the action theory, for which failure can serve merely as a negative delimitation for social action. I follow here Junge's proposal to ground the analysis in biographical research; yet my proposal diverges from his insofar I am not interested in how people cope with failure but I try to establish how they construct their biographies as successful. Placing "failure" within the context of action theory offers a perspective for considering failure through the more general prism of how individuals encompass uncertainties in respect to their own future in their life strategies (Zinn, 2004; Douglas, 1992; Slovic, 2010). Yet so far biographical research has focused primarily on "external," technological and environmental, risks. Complementarily, the studies of "status passages" (Schittenhelm, 2005), draw our attention to the uncertainty and risks involved in situations of transitions from one social position to another, for example from school to employment. As Reiter (2010) demonstrates with regard to the example of youth in a post-socialist context, the normative expectation to undertake employment after completing education creates for young people a risk of unemployment 
being understood as failing to fulfill this expectation. This situation can be analyzed considering how individuals mobilize their resources to appropriate future outcomes of their action and in response to societal requirements and norms (Reiter, 2010). This approach thus offers a framework for including subjective perceptions of the risk of failing as relevant for human action, and simultaneously allows the analysis of social norms of success and failure. As people struggle to meet normative expectations of success, failure is accessible to sociological analysis through the investigation of biographical narratives of success.

\section{Research sample and methods of investigation}

The data for this article comes from biographies of 44 Polish post-2004 post-accession immigrants to Great Britain interviewed between November 2010 and August 2011. The Poles now constitute the largest single national group among the post-accession migrants in Europe. The Polish case is instructive for the elaboration and modification of the body of theory and research that emerged in the context of immigration to the USA (Favell, 2008): in particular, it offers new insights into the question on the durability of de-skilling of a large number of migrants whose legal status and educational attainments would qualify them for more demanding and better paid jobs. The context of successfully transforming the Polish economy may offer corrections to theories departing from a center-periphery American migration system linking the US economy with often remote communities in Mexico and elsewhere. For the purpose of this article I abstain from a detailed analysis of the structural and macro-economic dimensions of these processes; instead, I argue that the biographical analysis provides us with an important perspective that goes beyond the simplified understandings of migrant economic integration in the country of residence (see Apitzsch and Siouti, 2007).

I and two contracted interviewers interviewed 25 women and 19 men; they were aged 21 to 43 , on average 28 years of age. Nineteen informants lived in London at the time of interview, and 25 in the Midlands region. This corresponds to the statistical information we have on Poles in the UK: the Polishborn population in the UK is estimated to be 532,000 people, widely spread across the UK. London has 122,000 Polish-born residents, 23 per cent of the UK total (ONS, 2011), and it draws many highly qualified career-oriented young people. The Midlands was chosen as this region hosts many industries providing employment to about 30,000 Polish immigrants (Green et al., 2007). An estimated 20 per cent of all post-accession migrants have university degrees; 33 per cent have secondary and secondary vocational training (Fihel and Kaczmarczyk, 2009). Among the informants, three persons had secondary vocational training, nine obtained general secondary certificates, and 19 completed higher education. Nine people studied either in Poland or in the UK while jobbing (for at least three months) in the UK. At the time of migration, 26 interviewees worked deskilled, and at the time of the interviews, this was still the case for 19 of them. 
The project design drew on the implementation of biographical research in migration studies that focuses on the life course of migrants in retrospect (Apitzsch and Siouti, 2007). We used narrative interviews (Schütze 1983) asking the informants to tell us first about the event of migration and stipulating them to narrate more about education and employment, family and friends, and everyday cultural encounters. At the end of each interview, we also explicitly asked how our interlocutors judge migration. In the analysis, I carefully consider whether the narration on success or failure was prompted by the interviewer or appeared spontaneously in the course of the interview. Biographical narratives which we gathered allowed the study of the intersections of biography and societal processes (Kohler Riessman, 2002), including beliefs and expectations regarding educational choices, employment, and the constitution of family and gender roles. Individual narratives are penetrated by discourses (Tuider, 2007) and thus reveal the shifts in understanding of 'normal' life trajectories; they are positioned in time and space, and thus can put light on the differences and similarities in individual and collective meanings between the country of origin and residence of migrants.

The analysis followed the framework suggested by grounded theory (Strauss, 1987). In several stages I first identified and labeled the phenomena and later classified them (Strauss and Corbin, 1996: 44ff). Further, I ordered the descriptive concepts into categories of an abstract character. Subsequently, I compared the categories with each other and with the literature (Strauss and Corbin, 1996: 188ff.). Here I drew on the biographical action research which is concerned with the way individuals respond to certain problems (Zinn, 2010). I was particularly sensitive in my analysis to how individuals consider success and failure a result of the condition of their own actions or as an outcome of circumstances external to the them; in this sense, informants might consider failure as controllable and possible to "repair"" or believe themselves not to have any influence over it. Also, I considered who and what constitute a reference frame for the individuals; some might consider failing from the perspective of their own career aims; others might orient their perceptions based on friends, colleagues, family members or famous people. Further, this also includes time frames in which one sets one's own aims for personal and career advancement.

The empirical material turned out to offer a very rich account of a variety of perceptions, biographical rationalizations and narrations on success and failure. Often I was able to distinguish three or four such narratives overlapping or competing in a single sentence. I discuss the selected ones at length because they are specific to transnational migration.

\section{Migrants narrating success and failure}

Our informants strived to present themselves as successful individuals in the context of professional life. This may seem unsurprising given that economic reasons were a strong motivation for many Poles to seek employment in the UK (Milewski and Ruszczak-Żbikowska, 2008), strengthened by the anxiety of unemployment that drives young Poles to assign greater value to work as such (Tuziak, 2004). The post- 
accession migration from Eastern Europe is usually considered a success to national economies which gained new labor force (Kahanec and Zimmermann, 2009). However, many of the workers in paid employment in the UK are high-quality migrants in low-wage jobs (Anderson et al., 2006) which is clearly at odds with their "livelihood" aspirations to upward social mobility for themselves and their (potential) children (White, 2009). Our informants often reflect about their own de-skilling and their deep disappointment with work in the UK. How then do the informants define success if they admit to performing routine, low-paid and dull tasks without good prospects for advancement? So far, the scholars studying Polish migration have discussed this discrepancy in terms of motivation to work (selfdevelopment opportunities substituting for money and prestige) (ex. Pollard et al. 2008; Janta et al. 2011), failing to provide us with convincing explanatory modes that sufficiently considers the complex structures of biographical narrations in a transnational context.

A systematic comparison of the collected individual biographies allowed me to distinguish three aspects, which I discuss on the basis of quotations from the selected, most representative interviews.

\subsection{Successful to-be}

Towards the end of each interview, we asked our informants to estimate whether they are successful. We received quite heterogeneous narratives. Informants typically circled around the tasks they perform at work, then shifted towards family and friends, and finally changed the temporal framework. Asked if she is successful, Zofia ${ }^{1}$ (master's degree, now in disabled care) stated:

I tell you, not really [laughter]. I do not consider my job as success. At the moment I am happy that I have a job and income but I am not happy in this job.

As Zofia, other informants considered success to mean doing interesting and ambitious work, and also as being able to progress on the job towards more complex work processes or responsibilities; this attitude is more common in the interviews that we conducted with men. This aspiration corresponds to the hierarchies of work-related expectations of Poles, in which seeing a sense in performed tasks is valued higher than income (Moczydłowska, 2007). Zofia then continued in response to our question on success:

In general I am happy, I have good friends, I am not alone, they support me, my boyfriend, my sister, my parents, in fact mostly my mom but if I am successful, no I cannot say that.

She evaded the topic of success in profession by shifting our attention to her Polish social network that offers her steady emotional support. It was quite common for our informants to locate success defined in terms of happiness in the private sphere and social network that stretches across large distance. Here, success appears as a highly individualized situation that is an outcome of personal effort understood as emotional investment in one's social network. It is mostly women who seek alternative

\footnotetext{
${ }^{1}$ All names have been changed to assure anonymity of the respondents.
} 
forms of success in having good friends and family life, including being healthy, and aspiring for better opportunities for their own children (van den Berg, 2011). The transnational dimension of these narratives is very strong as the informants position themselves relative to events and attitudes in Poland. The shift in the narratives from success in terms of employment and economic gain towards non-material aspects corresponds to the aspirations of non-migrant Poles, who focus on family life and personal wellbeing, as identified by a CBOS (2008) value survey. These attitudes constitute the embodied cultural capital that Polish migrants bring with them, and which they mobilize in the migration context as a strategy for coping with unsatisfactory employment.

Zofia's narration went on:

I am too busy right now, I also want to sell my flat in Poland, repay the debts here. In the coming years I want to complete this course and move to a Spanish-speaking country. We will see. This would be my success. [laughter]

Zofia locates her success in an undefined future. She constructs her biography as success-to-be, whereupon she disjoints her past experiences and the present expectations toward her future. By shifting to speak of the future, Zofia managed to draw our attention away from her present situation.

Also, when not prompted to ponder upon success in life but asked to describe their employment trajectory in the UK, and generally their life in the UK, the informants often made references to a lifestage for which it is rather atypical to be successful. This argument is used despite the fact that these "temporary" jobs turn out to be long-term work; our informants often combined it with other strategies. For example, Mirek (master's in economics), uses multiple strategies while trying to convince his girlfriend and the interviewer of the bright sides of his job as a packer:

(...) always after a recession, things will go up. Sooner or later, so if we now endure...Really, we are here since just a year. Look: you finished the studies, there are some problems with the job, but you do have a job, or? I do not coin money but I am now learning a bit how to manage people, work processes, cool. We are managing. We were on holiday in Turkey, weren't we?

He refers to a difficult situation on the labor market on which the couple does not have any influence; he argues that their time has not yet come (Goffman, 2008) when he considers his wife's current (parttime) job as fitting the stage of life; he mentions learning new skills which he can apply later if promoted. This strategy points to a logic of discontinuity underlying own life projects; while each stage in life is treated as a separate project, passing through one stage (education) to another (employment) is thus about starting anew; being successful in one does not result automatically in success in another. Through the reference to external circumstances and by stressing the temporal character of deskilling, he employs the strategy of enduring (Honkasalo, 2008). The "enduring" informants do not look back to the event failure in achieving their goals - but to the uncertain future, while not losing faith in a positive turn of the situation. Adam (master's in science, now in catering service), summarized this well when saying: "My life is not very successful, it is waiting." 


\subsection{Successful earners}

We asked the informants to tell us how they came to the UK. They told us first about their decision to leave Poland; then they spoke about their decision to stay in the UK. Zofia said:

So I stayed, unfortunately. I mean fortunately, because when I now compare the standard of living in England and in Poland (...) here I earn money for which I can afford holidays, going out in the evenings, even saving, buy good cosmetics. In Poland I know people who stayed and who do not do well, for example they got a job in a bank, as, let's say, cashier, and you know, they scrape together money at the end of the month, yeah? And they also do not work in their profession, despite their master degrees.

The narrative of earning decent money is very prominent in the interviews we collected. In the context of success and failure, it means an interesting shift from understanding success in terms of fulfilling employment situation to satisfying economic needs. Zofia defines her earnings as "sufficient" to pay her bills and being able to save a bit for little "extras". She discursively constructs a particular vision of "normality" (Galasińska and Kozłowska, 2009; Galasinska 2010) as the easiness of earning money, decent pay for work, and the possibility to afford hobbies.

Zofia's narrative displays that she constructs her biography in multiple reference to the significant others in Poland; it means she justifies her status in the UK vis-à-vis friends, relatives and unknown peers in Poland. In this sense, it also reflects that the unemployed are stigmatized in Poland (Bańka, 1992; Makselon-Kowalska, 1998). When judging her circumstances according to the "rules of her place of origin" (Kelly and Lusis, 2006), Zofia evades the discrepancy between the economic gain and loss of social status abroad (Eade, 2007). Moreover, this transnational orientation allows Zofia to draw our attention away from the question whether she succeeded in improving her life situation by migrating to the UK - and thus the suspicion that she failed to do so - towards the success she achieved (in her own words) in contrast to the general collective of non-migrant university graduates in Poland who "get stacked" in dull, badly paid jobs; she clearly distances herself from those individuals.

This rationalization is strengthened through the reference Zofia made to what she described as the "uselessness" of her education profile in political sciences. She said: "When you study political sciences you can work anything afterwards." She downplays her loss of status in the UK while she tries to draw our attention away from the labor market to the value of general education enabling her to develop new market-oriented competences. On the other hand, to the beginning of this narrative, Zofia refers to a "collective faith" she shares with other Poles. This narrative links deskilling in the UK with certain features of the Polish educational system. Our informants stress that the higher education institutions in Poland request more learning by heart, while the British system puts greater value on knowledge directly applicable on the labor market. Therefore, they are convinced that they have skills of no use in the UK. At the same time, they believe that Polish educational system produces people with a low self-esteem, contrasted with the British high self-esteem learnt at school, where children are 
frequently lauded for the smallest of achievements. When the two cultures clash, as is the case with Polish immigration to the UK, a certain "natural" hierarchy develops in which the British see themselves as superior to Poles. This rationalization makes our informants more prone to accept some forms of discrimination on the labor market in the UK.

\subsection{Successful humans}

Often the narratives on employment in the UK ended with stories of personal maturation through migration. Our informants consider in particular the ease of earning a living a means for achieving psychological wellbeing. Emilia's case is representative of this path. Each time Emilia's narrative started with her trouble in finding any kind of job in the UK, it then shifted to new qualities of her personality:

I've got more relaxed in the UK. (...) I think I've also learned to be more tolerant towards other people (...) I am maturing because of age but I also think that living here has helped me (...)

But then she went on to shift towards issues of liberalization and modernization:

Lately a friend asked me if I still have these red sneakers. Yes, I do, I replied. She said: "Would you wear them in Poland?" First I said yes. She replied: "But you would not wear them if you'd continued to live in Poland." And I said: "In Poland, I wouldn't get an idea to buy red shoes." Such banal things. People whom I meet in Poland now they say I am... I am calmer, and relaxed.

Emilia (general secondary education, jobs in community service) speaks further of how she gained time to care for her appearance, and she contrasts this with her friends' behavior in Poland. She then adds that her "life stretched" - she sees older people, retired, who have enough resources and energy to start up something new, and it gives her courage not to give up her own dreams, which she may not be able to realize now, but will achieve later. Other informants also said that they gained a new perspective on the "good life." They develop a narrative in which they cut themselves off from the backwardness and tradition (comp. Buijs, 1993) that they see dominating life in Poland. Some informants spoke of this personal evolution in spiritual terms, of knowing where they belong.

The narratives of maturation re-appeared in the interviews when we asked explicitly whether the respondent considers his or her migration to the UK to be a success. Adam (master's in science, employed in catering service) said:

[Migration] was a success, yeah. Because...I think that you know...I've developed a bit, I've changed the opinions, my horizons widened. I think how to develop further (...) and I am liberated regarding some issues.

He then explained that self-development means to discover one's own potential and to use it to "make something of life." He thereby stressed: "There are so many things that comes to consideration successful," and elaborated: 
You develop potential to do something about your life, in the sense of travelling, working, meeting interesting people, coping in unfamiliar cultures, experience cultures, becoming a citizen of the world.

While Adam stresses the personal liberation and maturation that make migration a successful experience for him, Tomek (general secondary education, manual worker) and Emil (lawyer, now assistant in a bank) instead compare themselves to other migrants from Poland. Tomek stated that, "not everybody manages to migrate," alluding to those Poles who, presumably involuntarily, returned home. Managing to earn his living in a foreign country became a source of prestige and status for him. Self-sufficiency in an unfamiliar environment is thus itself a new asset. Kelly and Lusis (2006: 843) speak in such cases of an "elevated cultural capital."

Emil's case is interesting insofar as he compared his condition to that of other Poles in the UK. Asked whether he thinks he was successful, Emil said:

Yes (...) yeah, I feel that I am a foreigner and clearly I am a Pole, but in comparison to so many Poles that I got to know here, this is so to say just my private opinion: I think, I stand at the highest position.

Emil thus constructs his personal success relative to other migrants from Poland in the UK. The question on migration as success prompted his narrative about the other group of Polish immigrants who are a shame for all Poles in Great Britain and in Poland (Svasek, 2009). Our informants clearly distanced themselves from them by stressing that these "others" think only of money and therefore have "no culture." Such a narrative - next to a symbolic positioning within a competitive field -works as a foil to draw our attention towards a relative success.

\subsection{Failing others}

Failure becomes more explicit in the narratives about other Poles in Great Britain. These narratives appeared prompted by our questions: We asked our informants whether they think new Polish immigrants to the UK are successful, respectively whether migration to the UK was a success for them. Additionally, the narratives about other Poles and their success/failure spontaneously appeared when the informants narrated their own employment paths in the UK. Irrespectively of where in the interview they appeared, two aspects are central to these narratives: family bonds versus family disintegration, and progress versus stagnancy.

In the light of earlier findings, it is no surprise that women in particular consider the disintegration of families as a main loss for migrants from Poland. They told us about couples who split, and children who were left behind by their parents. Luiza (tertiary education, manual worker), when asked for her opinion on the decision for migrating taken by so many Poles in recent years, said: "For some surely a failure because some, you know, they lost their families." She contrasted her personal trajectory with such stories and said her relationship to her boyfriend had survived the move to the UK and developed positively in the new location; she considers this a success. 
The narrative of stagnancy and progress is more complex. When asked to judge whether the new Polish immigrants in the UK are successful, Janek elaborated on what he termed a "migration trap" into which the Poles fall when they earn enough to afford a comfortable life but they live from day to day and have no incentives to make long-term plans. Lena (master's degree, elderly home care) employed this kind of argumentation more explicitly in the context of success and failure:

I want to believe a success. Because they proved as I did that they can manage. Even people without any English language skills change their lives by 360 degrees and manage it here, and live here.

Janek and Lena define success as progress and standstill as failure related to migration. It is a question of a change in one's life that decides whether someone is successful or not. Janek shifts between defining progress in terms of professional career development and maturation as a human being. Both Janek and Lena consider success and failure to be a personal achievement of an individual who takes decisions on whether and how to develop. They assign responsibility for failing entirely to the migrants; within this framework, they can present themselves - in contrast to the other, failing Poles - as successful individuals who are progressing in their professional but most importantly in their personal development. Some ethnicised qualities of their characters, such as being focused, hardworking, ambitious, and spiritual (Janek in particular refers to his deep engagement with the Polish Catholic Church), makes them successful individuals. They contrast these qualities with the laziness, lack of moral norms and the criminal energy typical of - as they claim - most Poles in the UK.

Lena took a different position when speaking about Polish migrants to the UK:

There are many people who are successful in their profession but we also hear about people, perhaps now less frequently, who sleep at Victoria Station in paperboard boxes. They have no money to return but I think this is not failing, I think they had not been prepared sufficiently and then a small failure, no support. Had they moved from Tomaszow [provincial town in Poland] to Warsaw, or Gdansk, it could have ended for them the same way. So I want to believe for most it [migration] is a success.

She blames a particular constellation of circumstances that makes some people less successful than others, thereby alluding to the transformation in Poland (Burrell, 2011). She frees individuals from the responsibility for succeeding or failing. She discursively minimizes failure to a trifle that might happen to anybody, whereby her narrative reveals anxiety about being stigmatized as someone who fails. She reduces failure to a momentary situation, and de-links it from international migration.

When asked to evaluate their (and others') migration decision, the informants narrated on success in terms of the continuum between professional and family life and in respect to their future. Second, the narratives on success-to-come were accompanied by discourses of success defined as earning a living or personal maturation; these narratives appeared when informants described their own employment trajectory. Considering the three aspects jointly, we can observe discursive shifts from defining success as a condition of one's own action to an outcome of conditions external to the individual and in reference to a kind of collective faith of Poles. On the other hand, these narratives move between 
considering success within the framework of one's own life course and personal career goals and a transnational framework of reference that includes those left behind.

Failure, if explicitly addressed in the narratives, appeared as loss of family bonds and lack of progress. In most of the narratives, however, failure remains silent but it is present as a risk. It is constructed in contrast to a normative expectation of progressing in a professional career, and not meeting this expectation while working deskilled, the informants struggle to discursively present themselves as successful earners. Facing the wish (one's own and others') of higher earnings, the interviewed migrants describe the process of maturation and liberalization that makes them more, or at least not less, successful than those who stayed behind. The temporal and spatial stretch of the narratives shows how the informants use transnational orientation as a biographical resource in the struggle for recognition from distant others and to navigate around the notion of failure to present themselves as successful individuals.

\section{Concluding remarks}

For success and failure, migration matters in many ways. First, the informants define it as a break point in their life-projects. In these narrations, discontinuity veils a lack of success. Second, migration means moving to a new socio-cultural space which as such is a challenge; our informants emphasize that finding employment and managing the everyday in a new environment is already a type of success that is not accessible to everybody. Third, migrating into a new socio-cultural space can be a source of new cultural capital, which our informants often describe in terms of modernization, a break with the traditional division of gender roles, an escape from the backwardness of Polish society, and learning new civility in the UK. Fourth, migration, as a move between two national systems, is shaped by the incomparability of nationally formed education and skills, which the informants use as a rationalization for their lack of professional success. Fifth, through migration, our informants gained a new system of reference and new peer-groups with which they compare themselves.

The last finding contributes to the scholarship on transnational migration. In most of the narratives, the informants struggled to create a sense of positive distinction from those left behind. These are the narratives of relative success that neutralize or avoid the notion of failure. It's possible for the informants to claim their relative success only by applying a double perspective on what success and failure are: They often implicitly place themselves at the bottom of the social ladder in the UK when comparing their earnings and prestige of their jobs to their fellow workers in the UK (Nowicka, 2012), and then more explicitly apply the rules of the country of origin to relativize their situation in comparison with specific friends and in general with Poles who stayed. Often, they also imagine their own wouldbe position in Poland in order to present their current situation in the UK as relatively successful. This kind of self-reflexivity results from a transnational character of this migration. Being involved in a transnational social space, migrants gain new possibilities of valuation and elevation of cultural capital, 
which then become a valuable resource in coping with the devaluation of institutionalized cultural capital such as school certificates.

'Cultivated uncertainty' regarding settling in the UK or return to Poland (Milewski and Ruszczak-Żbikowska 2008), and the existence of transnational ties and orientations of Poles in the UK, result in shifting of temporal frameworks in which failure and success become defined: Poles we interviewed often discursively postpone their desires to a later point in time, arguing that life is unpredictable and uncertain. Uncertainty is in this context a resource for self-presentations as a person who is capable - in terms of having sufficient and desirable cultural capital - of success in the future. Through the reference to the future, failure becomes a non-existing category of the present day but it remains relevant to migrants as a "risk". This implies that migrants are at least potentially capable of actions to avoid or minimize this risk. As migration is about constantly building up new resources to cope with unexpected and adverse situations, failure becomes a dynamic notion relative to success, and yet is not it's opposite.

The findings challenge the conventional understanding of failure as a cause of (postponed) return migration and they also exhibit the deficiencies of the approaches that oppose financial success to, and substitute it with self-development desires of migrants, which might make them more inclined to settle than to return. Studies on return migration so far looked either at migrants' subjective motivations and intentions, or involved the notion of 'failure' when considering the 'objective', structural conditions of migrant labor market participation. Transnationalism has so far been considered in this context as social ties and economic remittances of migrants to their place of origin (de Haas and Fokkema 2011). Yet when migrants constitute their biographies as successful-to-be and failure (for example lack of sufficient or any employment or income) as merely an avoidable risk, structural indicators might turn insufficient to predict inclination to return or settlement. Transnational orientations, in particular a double system of reference, enable migrants to sway their subjective assessment of success and failure between multiple social and national contexts, and consequently to adopt their motivations and strategies of settlement or return accordingly. 


\section{Bibliography}

Ackroyd, S.

2007 "Organizational Failure", in G. Ritzer (Ed) Blackwell Encyclopaedia of Sociology.

Blackwell Reference Online DOI: 10.1111/b.9781405124331.2007.x.

Anderson, B., M. Ruhs, B. Rogaly, and S. Spencer

2006 Fair enough? Central and east European migrants in low-wage employment in the $U K$. York: Joseph Rowntree Foundation.

Apitzsch, U. and M. Kontos

2008 Self-employment activities of women and minorities: Their success or failure in relation to social citizenship policies. Wiesbaden: VS.

Apitzsch, U. and I. Siouti

2007 Biographical Analysis as an Interdisciplinary Research Perspective in the Field of Migration Studies. Report. University of York. April.

Bańka, A.

1992 Bezrobocie. Podręcznik pomocy psychologicznej. Poznan: Print.

Buijs, G.

1993 Migrant women: Crossing boundaries and changing identities. Oxford: Berg.

Burrell, K.

2011 "Opportunity and uncertainty: young people's narrative of "double transition" in postsocialist Poland" Area 43(4): 413-9.

Caglar, A. and N. Glick Schiller

2008 Migrant Incorporation and City Scale: Towards a Theory of Locality in Migration Studies. WP 2/07. Malmö: Malmö University.

CBOS

2008 Aspiracje Polaków w latach 1998 i 2008: Komunikat z Badań BS/155/2008.

De Haas, H. and T. Fokkema

2011 "The effects of integration and transnational ties on international return migration intentions", Demographic Research 25, Art. 24

Douglas, M.

1992

Risk and blame: Essays in cultural theory. London: Routledge.

Eade, J.

2007 Poles apart? EU enlargement and the labour market outcomes of immigrants in the $U K$. IZA Discussion paper. Bonn.

Favell, A

2008 "The New Face of East-West Migration in Europe." Journal of Ethnic and Migration Studies 34(5): 701-16.

Fihel, A. and P. Kaczmarczyk

2009 "Migration: A Threat or a Chance? Recent Migration of Poles and its Impacts on the Polish Labour Market", in K. Burrell (Ed.) Polish migration to the UK in the 'new' European Union: After 2004. Burlington: Ashgate, pp. 23-48. 
Galasińska, A.

2010 "Leavers and stayers discuss returning home: Internet discourses on migration in the context of the post-communist transformation" Social Identities 16(3): 309-24.

Galasińska, A. and O. Kozłowska

2009 'Discourses of a 'Normal Life' among Post-accession Migrants from Poland to Britain", in K. Burrell (Ed.) Polish migration to the UK in the 'new' European Union: After 2004. Burlington: Ashgate, pp. 87-106.

Goffman, E.

2008 "On Cooling the Mark Out: Some Aspects of Adaptation to Failure", in E. Goffman and C. Lemert (Eds) The Goffman reader. Malden, MA: Blackwell, pp. 3-20.

Green, A., D. Owen and P. Jones

2007 The economic impact of migrant workers in the West Midlands. Report. IER \& BMG Research.

Honkasalo, M.-L.

2008 "Enduring as a mode of living with uncertainty", Health, Risk \& Society 10(5): 491503.

Janta, H., A. Ladkin, L. Brown and P. Lugosi

2011 "Employment experiences of Polish migrant workers in the UK hospitality sector", Tourism and Management 32(5):1006-19.

Junge, $\mathrm{M}$.

2010 „Scheitern und Scheiternsbewältigung - Eine soziologische Betrachtung“, in H.

Pechlaner (Ed) Scheitern: die Schattenseite des Daseins. Berlin: Erich Schmidt, pp. $31-46$.

Kahanec, M. and K. Zimmermann

2009 Migration in an enlarged EU: A challenging solution? Economic Papers 363.

Brussels: EC.

Kelly, P. and T. Lusis

2006 "Migration and the transnational habitus: evidence from Canada and the Philippines", Environment and Planning A 38: 831-47.

Kohler Riessman, C.

2002 "Analysis of Personal Narratives", in J. Gubrium and J.Holstein (Eds) Handbook of interview research: Context \& method. Thousand Oaks, CA: Sage, pp. 695-710.

Kohli, M.

2007 "The Institutionalization of the Life Course: Looking Back to Look Ahead", Research in Human Development 4(3-4): 253-71.

Makselon-Kowalska, B.

1998 „Atrybucje przyczyn utraty pracy a wybór strategii zaradczych przez osoby bezrobotne”, in T. Ratajczak (Ed.) Psychologia. Badania i Aplikacje: Bezrobocie., Katowice: Wydawnictwo Uniwersytetu Śląskiego, pp. 69-78.

Malpas, J. and G. Wickham

1995 "Governance and failure: on the limits of sociology", Journal of Sociology 31(3): 3750. 
Milewski, M. and J. Ruszczak-Żbikowska

2008 Motywacje do wyjazdu, praca, więzi spoleczne i plany na przyszłość polskich migrantów przebywających w Wielkiej Brytanii i Irlandii. CMR Working Papers No 35/93. Warsaw.

Moczydłowska, J.

2007 „Czynniki motywujące do pracy w ocenie pracowników mikro- i małych przedsiębiorstw Polski północno-wschodniej”, Zeszyty Naukowe Wyższej Szkoły Zarzadzania Ochrona Pracy w Katowicach 1(3): 69-74.

Nowicka, M.

2012 Deskilling in migration in transnational perspective. The case of recent Polish migration to the UK. Working Paper 112, COMCAD Bielefeld.

2013 "Positioning strategies of Polish entrepreneurs in Germany: Transnationalizing Bourdieu's notion of capital", International Sociology 28(1): 28-46.

ONS

2011 Migration Statistics Quarterly Report: August 2011.

Reiter, $\mathrm{H}$.

2010 "Context, Experience, Expectation, and Action - Towards an Empirically Grounded, General Model for Analyzing Biographical Uncertainty", Forum: Qualitative Social Research 11(1): Art. 2.

Schittenhelm, K.

2005 Soziale Lagen im Übergang: Junge Migrantinnen und Einheimische zwischen Schule und Berufsausbildung. Wiesbaden: VS.

Schütze, F.

1983 “Biographieforschung und narratives Interview”, Neue Praxis 13(3): 283-93.

Slovic, $\mathrm{P}$.

$2010 \quad$ The feeling of risk: New perspectives on risk perception. London: Earthscan.

Strauss, A.

1987 Qualitative analysis for social scientists. New York: Cambridge University Press.

Strauss, A. and J. Corbin

1996 Grounded Theory. Wienheim: Beltz.

Svasek, M.

2009 "Shared History? Polish Migrant Experiences and the Politics of Display in Northern Ireland", in K. Burrell (ed.) Polish migration to the UK in the 'new' European Union: After 2004. Burlington: Ashgate, pp. 129-48.

Tuider, E.

2007 "Discourse Analysis and Biographical Research. About the How and Why of Subject Positions", Forum: Qualitative Social Research 8(2).

Tuziak, B.

2004 „Praca jako wartość na tle orientacji wartościujących, zasad i celów życiowych pracowników-studium przypadku", in M. Woźniak (Ed) Nierówności społeczne a wzrost gospodarczy. Rzeszów: WUR, pp. 67-76. 
van den Berg, M.

2011 "Subjective social mobility: Definitions and expectations of 'moving up' of poor Moroccan women in the Netherlands", International Sociology 26(4): 503-23.

Wang, W.W. and C. Fan

2006 "Success or failure: selectivity and reasons of return migration in Sichuan and Anhui, China", Environment and Planning A 38: 939-58.

White, A.

2009 "Family migration from small-town Poland: A livelihood strategy approach", in K. Burrell (Ed) Polish migration to the UK in the 'new' European Union: After 2004. Farnham: Ashgate, pp. 67-85.

2013 "Polish Return and Double Return Migration”, Europe-Asia Studies, forthcoming.

Wimmer, A. and N. Glick Schiller

2002 "Methodological nationalism and beyond: nation-state building, migration and the social sciences", Global Networks 2(4): 301-34.

Zinn, J.

2004 "Health, risk and uncertainty in the life course: A typology of biographical certainty constructions", Social Theory \& Health 3: 199-221.

2010 "Biography, Risk and Uncertainty-Is there Common Ground for Biographical Research and Risk Research?”, Forum: Qualitative Social Research 11(1): Art. 15. 